\title{
MEDICAL EXPULSIVE THERAPY- AN EFFECTIVE TREATMENT OPTION FOR LOWER URETERIC CALCULI
}

\author{
Chirag Shanti Dausage ${ }^{1}$, Ranjit Chaudhary², Dhiraj Sharma ${ }^{3}$
}

${ }_{1}^{1}$ Resident, Department of General Surgery, Peoples College of Medical Sciences and RC, Bhopal, Madhya Pradesh, India. ${ }^{2}$ Associate Professor, Department of General Surgery, Peoples College of Medical Sciences and RC, Bhopal, Madhya Pradesh, India. ${ }^{3}$ Assistant Professor, Department of General Surgery, Peoples College of Medical Sciences and RC, Bhopal, Madhya Pradesh, India.

ABSTRACT
BACKGROUND
This is a prospective randomized trial to study the efficacy of medical expulsive therapy for lower ureteric calculi. Ureteral stones
are a global health issue. Almost 20\% of urinary tract stones are found in the ureter with majority (70\%) being located in the lower
third of the ureter.

\section{MATERIALS AND METHODS}

Patients diagnosed with lower ureteric calculi in the Department of Surgery, People's College of Medical Sciences and RC, Bhopal were included in this study. The study comprised of 180 patients which were randomly divided equally into three groups. Patients in the first group were subjected to conservative management; silodosin was added to those in the second group and patients in the third group were administered a combination of silodosin and deflazacort.

\section{RESULTS}

A statistically significant stone expulsion rate was seen in group 3 as compared to group 1 and 2 .

\section{CONCLUSION}

Medical expulsive therapy with alpha-blockers (Silodosin) and corticosteroids (Deflazacort) is effective for management of lower ureteric calculi and avoids surgical intervention in many patients.

\section{KEY WORDS}

Lower Ureteric Calculi, Medical Expulsive Therapy.

HOW TO CITE THIS ARTICLE: Dausage CS, Chaudhary R, Sharma D. Medical expulsive therapy- an effective treatment option for lower ureteric calculi. J. Evolution Med. Dent. Sci. 2019;8(01):67-72, DOI: 10.14260/jemds/2019/15

\section{BACKGROUND}

Ureteral stones are a global health issue. Almost $20 \%$ of urinary tract stones are found in the ureter with majority $(70 \%)$ being located in the lower third of the ureter.

The normal ureter has three distinct sites of narrowing namely the ureteropelvic junction, crossing of the iliac vessels and the ureterovesical junction. There is no intrinsic change in the ureteral caliber at first two locations. However, the ureterovesical junction has true physical restriction of the ureter as it makes the intramural passage through the bladder wall to the ureteric orifice. These three sites of ureteral narrowing are clinically significant because they are common locations for urinary calculi to lodge during passage.

The ureter contains both $\alpha$ and $\beta$ adrenergic receptors. Three different subtypes of $\alpha$ receptors have been pharmacologically identified: $\alpha 1 \mathrm{a}, \alpha 1 \mathrm{~b}$, and $\alpha 1 \mathrm{~d}$. The highest density of $\alpha 1 \mathrm{a}$ receptor binding sites was detected in the distal ureter. The distribution of $\alpha$ receptors throughout the inner and outer smooth muscle of the ureter was highest for $\alpha 1 \mathrm{~d}$, especially in the distal ureter, followed by $\alpha 1 \mathrm{a}$ and $\alpha$ $1 \mathrm{~b} \cdot[1,2,3,4]$

'Financial or Other Competing Interest': None.

Submission 28-09-2018, Peer Review 25-12-2018,

Acceptance 31-12-2018, Published 07-01-2019.

Corresponding Author:

Dr. Ranjit Chaudhary,

Associate Professor,

Department of General Surgery,

Peoples College of Medical Sciences and RC,

Bhopal, Madhya Pradesh, India.

E-mail:drnidhiranjit@gmail.com

DOI: 10.14260/jemds/2019/15

\section{MATERIALS AND METHODS}

A prospective and randomized control study of 180 consecutive patients visiting the Department of Surgery, PCMS \& RC, Bhopal over a period of 1 year (Jan 2016 to Dec 2016) that fulfilled the study criteria. 180 patients were randomly divided equally in three groups by computer generated numbers. Patients in the first group were subjected to conservative management, silodosin was added to those in the second group and patients in the third group were administered a combination of silodosin and deflazacort.

\section{Groups}

1. Conservative supportive treatment (Control group).

2. Medical expulsive therapy, group 1 (Silodosin $8 \mathrm{mg}$ ).

3. Medical expulsive therapy, group 2 (Silodosin $8 \mathrm{mg}$ with deflazacort $30 \mathrm{mg}$.)

\section{Inclusion criteria}

Age 15 to 65 years, stone size $\leq 10 \mathrm{~mm}$ in lower ureter.

\section{Exclusion criteria}

Presence of multiple stones, pregnancy, congestive cardiac failure, chronic renal failure grade III/IV/V, pyonephrosis, diabetes mellitus, any anatomical abnormalities (obstructive megaureter, vesico-ureteric reflux, ureterocele), previous history of steroid intake, previous history of surgery for urolithiasis, bilateral stones.

\section{Source of Data}

Clinical examination, laboratory/ radiology investigations, medical literature. 


\section{Study Tools}

Detailed history, clinical examination, skiagram and ultra-

sonogram of KUB region.

\section{Statistical Analysis}

The software used for statistical analysis is 22.0 and data was analysed using One-Way ANOVA test \& Fisher's exact between the groups and $\mathrm{P}<0.001$ was considered significant.

\section{RESULTS}

\begin{tabular}{|c|c|c|c|c|}
\hline & Male & Female & Total & p-Value \\
\hline Conservative & $40(66.6 \%)$ & $20(33.3 \%)$ & $60(33.3 \%)$ & \multirow{2}{*}{$<0.001$} \\
Silodosin & $42(69.3 \%)$ & $18(30 \%)$ & $60(33.3 \%)$ & \\
\cline { 1 - 3 } Silodosin +Deflazacort & $34(56.1 \%)$ & $26(42.9 \%)$ & $60(33.3 \%)$ & \\
\hline \multicolumn{4}{|r|}{ Table 1. Distribution of Patients According to Gender in Different Treatment Groups } \\
\hline
\end{tabular}

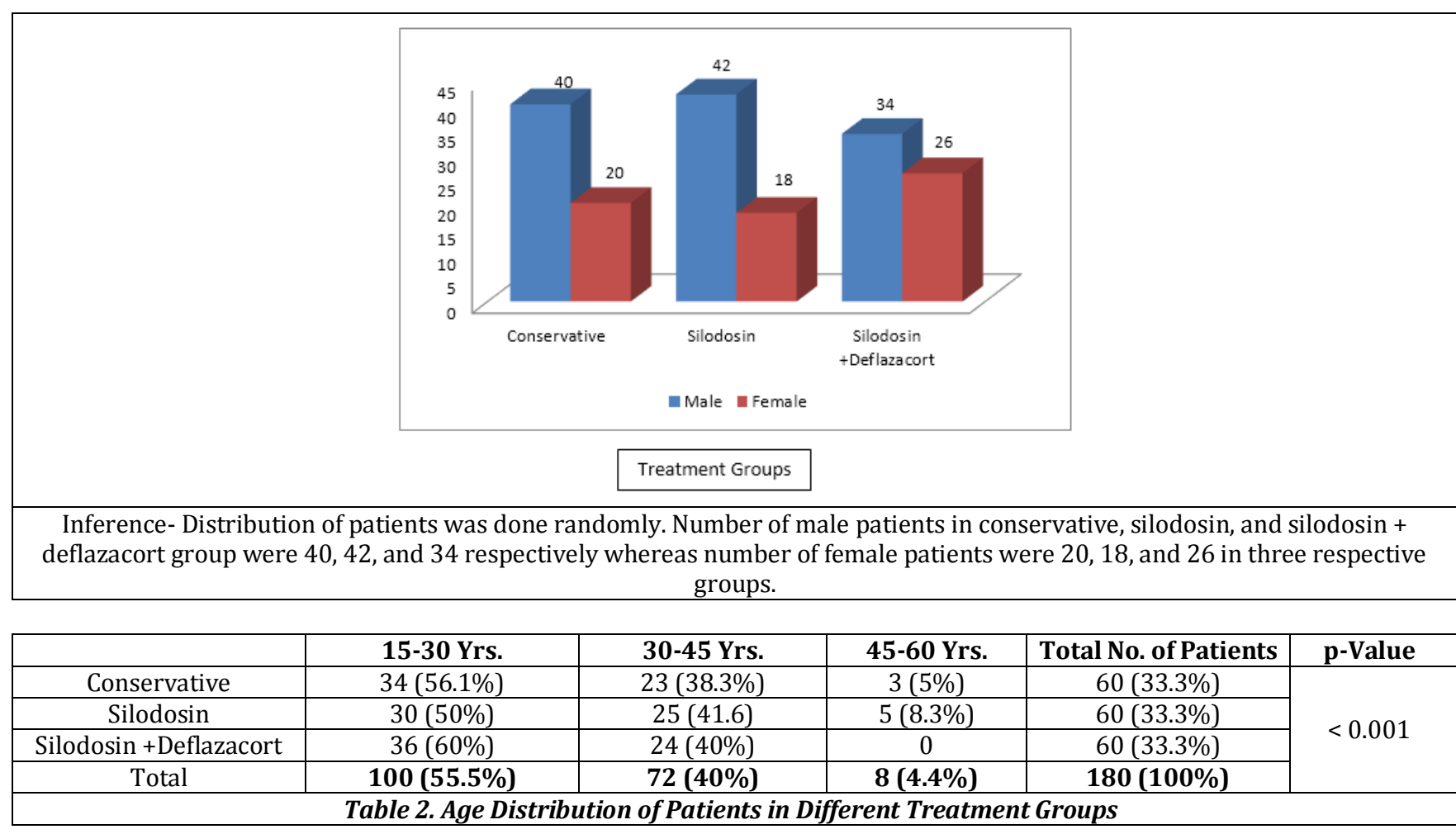

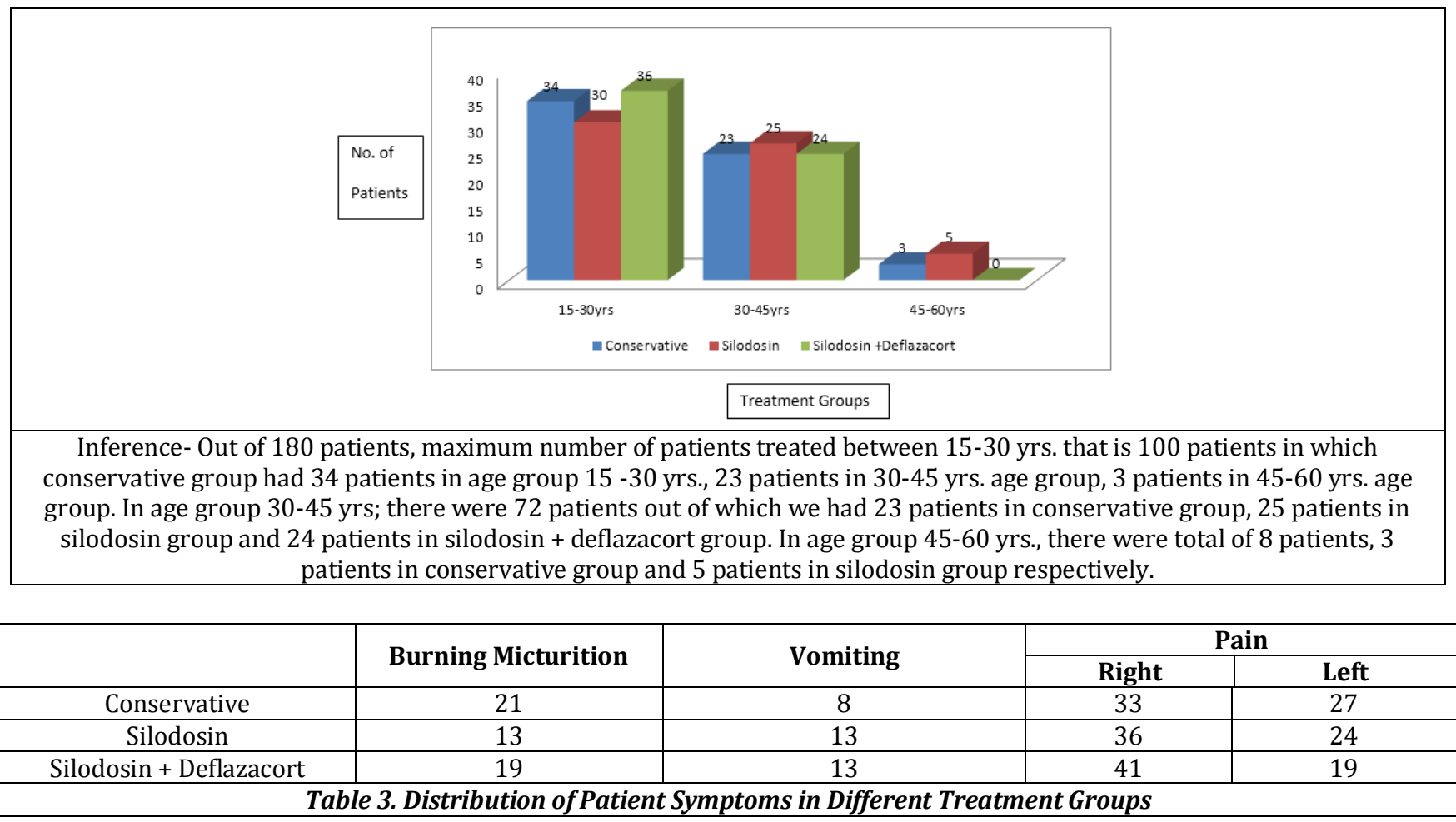




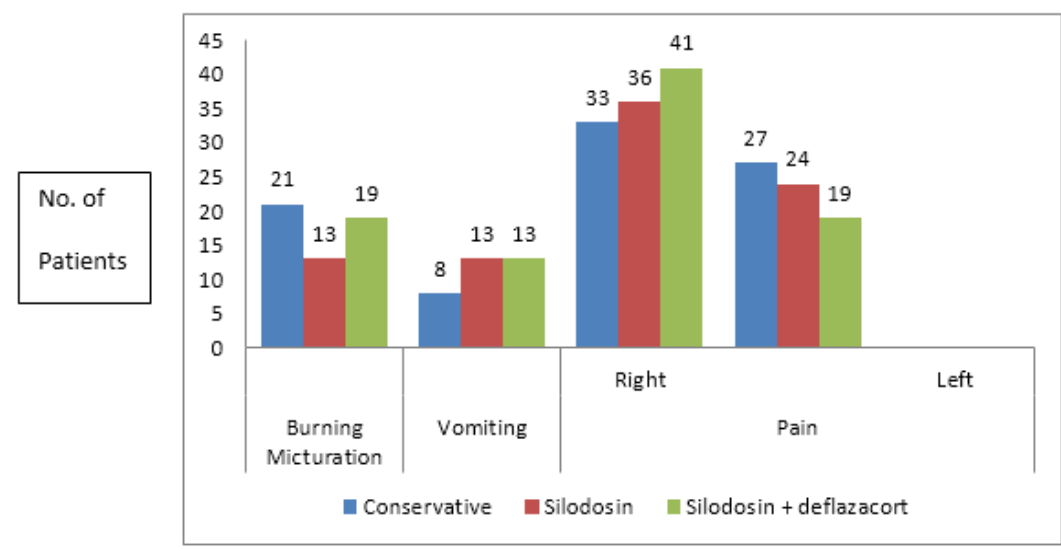

Patient Symptoms

Inference- Patients mainly presented with symptoms like burning micturition and vomiting. In conservative group 21 patients had burning micturition whereas 8 patients had complaint of vomiting. Similarly, 13 patients in silodosin group and 19 patients in silodosin + deflazacort group had burning micturition whereas 13 and 13 patients had vomiting in two respective groups. Out of total 180 patients 33,36, and 41 patients presented with right iliac fossa pain in three consecutive groups, whereas left iliac fossa pain was present in 27,24 , and 19 patients.

\begin{tabular}{|c|c|c|}
\hline & Right Ureter & Left Ureter \\
\hline Conservative & 33 & 27 \\
\hline Silodosin & 36 & 24 \\
\hline Silodosin + Deflazacort & 41 & 19 \\
\hline
\end{tabular}

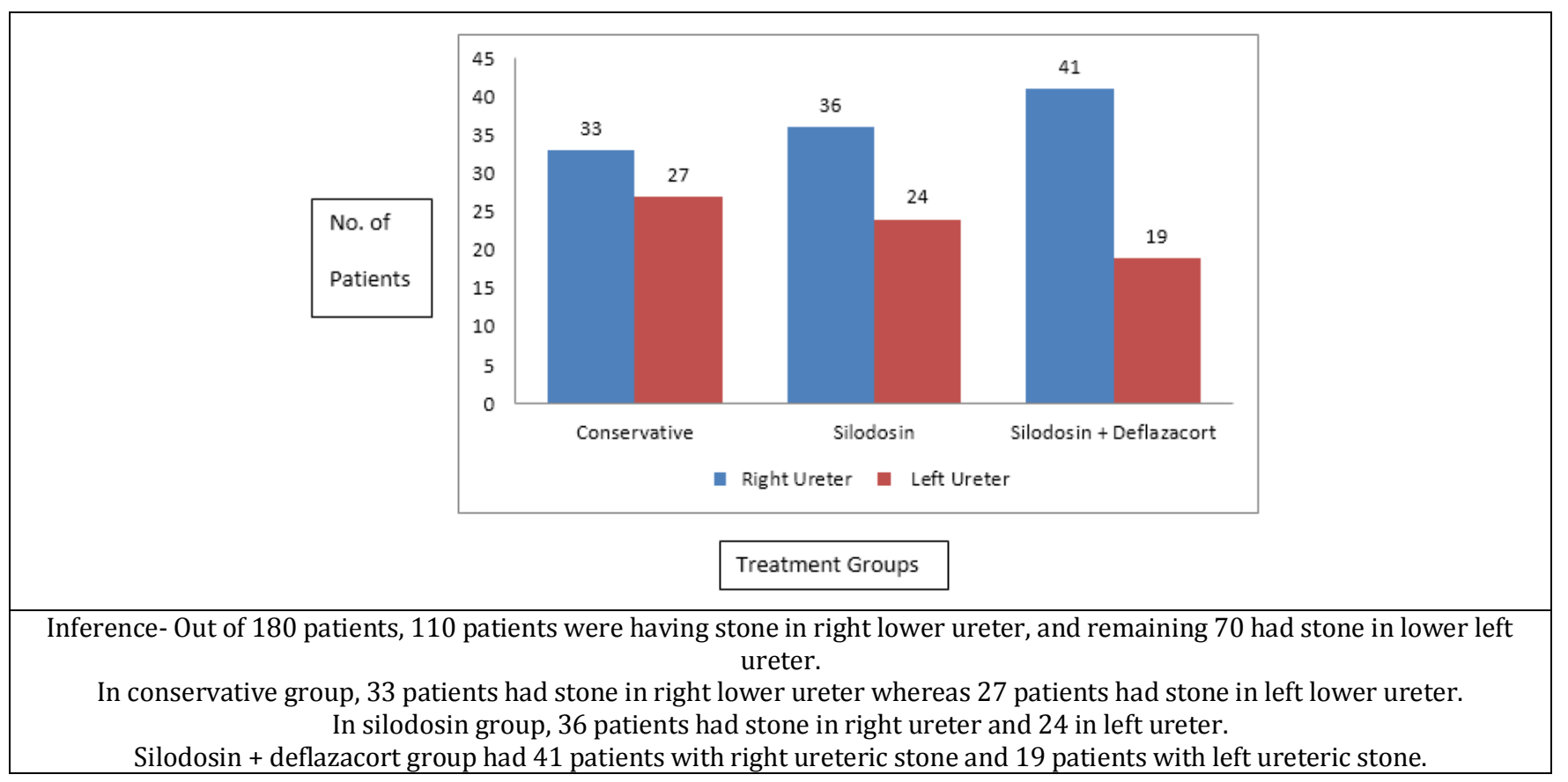

\begin{tabular}{|c|c|c|c|c|c|}
\hline & $\mathbf{n}$ & $\begin{array}{c}\text { Mean Stone Size } \\
(\mathbf{m m})\end{array}$ & SD & Range & p-Value \\
\hline Conservative & 60 & 6.06 & 0.82 & $5.85-6.27$ & \multirow{2}{*}{$<0.001$} \\
\hline Drug Silodosin & 60 & 6.20 & 0.75 & $6.05-6.39$ & \\
\hline Deflazacort and Silodosin & 60 & 6.23 & 1.01 & $5.97-6.49$ & \\
\hline \multicolumn{7}{r}{} \\
\hline
\end{tabular}




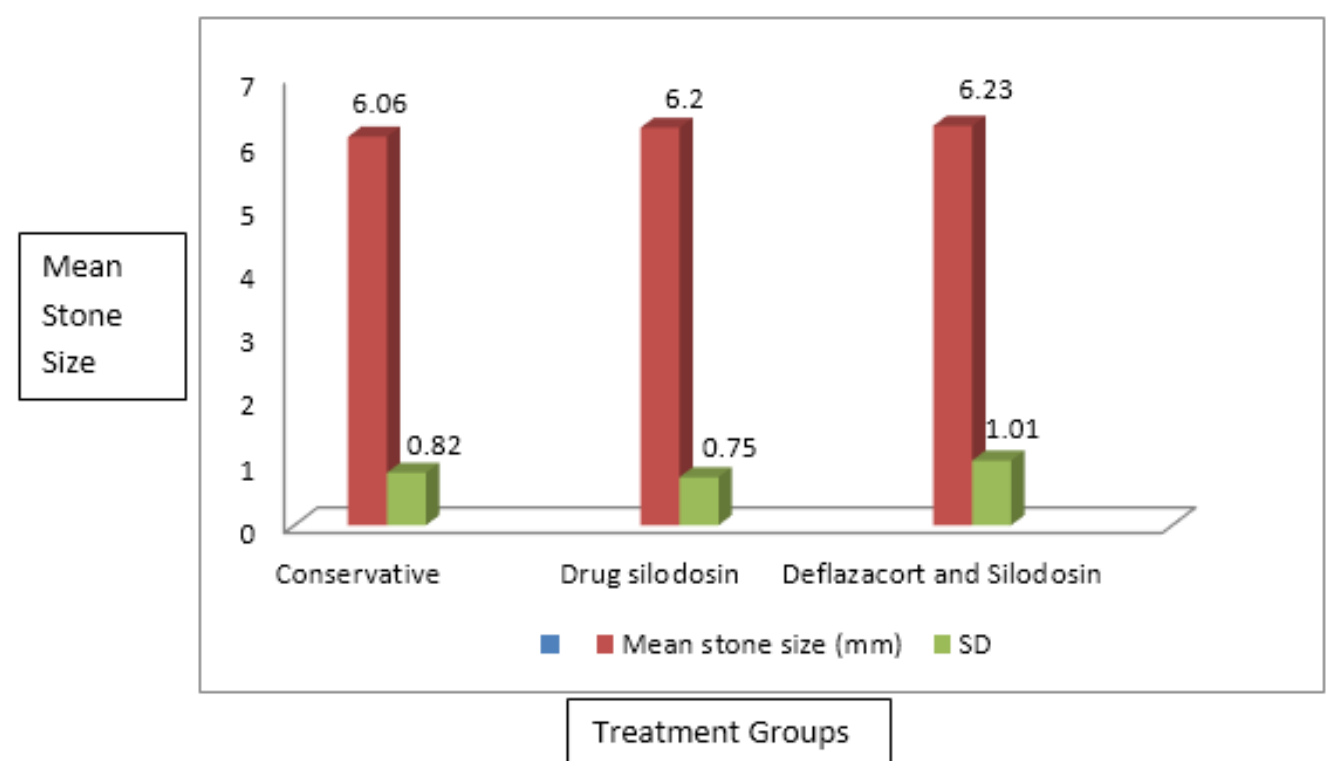

Inference- Mean stone size was $6.06 \mathrm{~mm}$ in conservative group with standard deviation of 0.82 . Mean stone size and standard deviation in silodosin group 6.20 and 0.75 , whereas in group silodosin + deflazacort it was 6.23 and 1.01 .

\begin{tabular}{|c|c|c|c|c|c|c|c|}
\hline & \multicolumn{2}{|c|}{ Conservative } & \multicolumn{2}{c|}{ Silodosin } & \multicolumn{2}{c|}{$\begin{array}{c}\text { Silodosin }+ \\
\text { Deflazacort }\end{array}$} & p-Value \\
\hline & $\begin{array}{c}\text { No. of } \\
\text { Patients (n) }\end{array}$ & $\begin{array}{c}\text { \% of } \\
\text { Patients }\end{array}$ & $\begin{array}{c}\text { No. of } \\
\text { Patients (n) }\end{array}$ & $\begin{array}{c}\text { \% of } \\
\text { Patients }\end{array}$ & $\begin{array}{c}\text { No. of } \\
\text { Patients (n) }\end{array}$ & $\begin{array}{c}\% \text { of } \\
\text { Patients }\end{array}$ & \\
\hline $\begin{array}{c}\text { Stone } \\
\text { Passed }\end{array}$ & 10 & $16.66 \%$ & 31 & $50.8 \%$ & 37 & $61.6 \%$ & $\begin{array}{c}<0.001 \text { (Combination vs Conservative) } \\
0.22 \text { (Combination vs Silodosin) }\end{array}$ \\
\hline \multicolumn{7}{|c|}{ Table 6. Number of Patients Which Passed Stone Until 7th Day of Treatment } \\
\hline
\end{tabular}

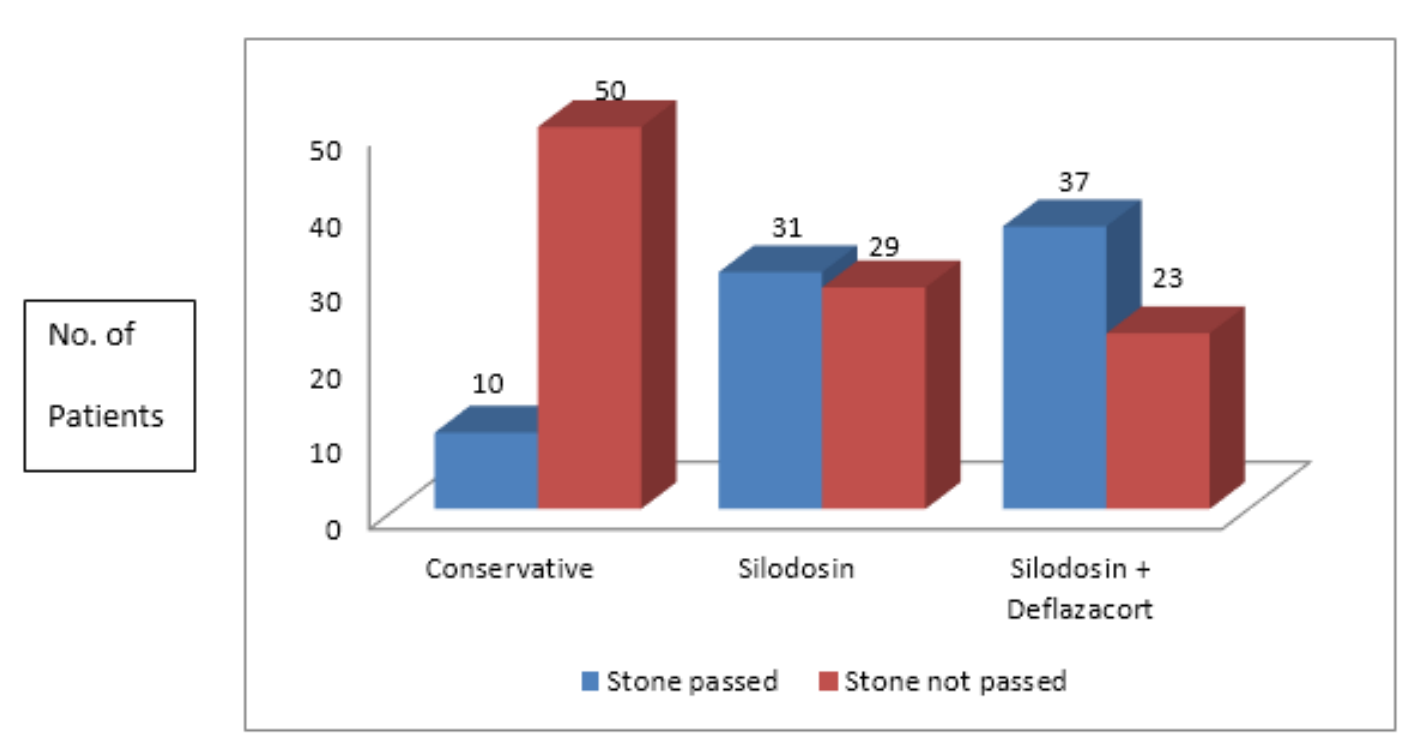

Treatment Groups

Inference- In conservative group out of 60 patients $10(16.66 \%)$ patients had passed stone till 7 th day. 31 (50.8\%) patients passed stone in silodosin group where as 37 (61.6\%) patients in silodosin + deflazacort group had passed stone till 7 th day.

\begin{tabular}{|c|c|c|c|c|c|c|}
\hline \multicolumn{2}{|c|}{ Conservative } & \multicolumn{2}{|c|}{ Silodosin } & \multicolumn{2}{|c|}{ Silodosin + Deflazacort } & \multirow[t]{2}{*}{ p-Value } \\
\hline $\begin{array}{c}\text { No. of } \\
\text { Patients (n) }\end{array}$ & $\begin{array}{c}\text { \% of } \\
\text { Patients }\end{array}$ & $\begin{array}{c}\text { No. of } \\
\text { Patients (n) }\end{array}$ & $\begin{array}{c}\text { \% of } \\
\text { Patients }\end{array}$ & $\begin{array}{c}\text { No. of } \\
\text { Patients (n) }\end{array}$ & $\begin{array}{c}\% \text { of } \\
\text { Patients }\end{array}$ & \\
\hline 14 & $23 \%$ & 38 & $63 \%$ & 53 & $88 \%$ & $\begin{array}{c}<0.001 \text { (Combination vs Conservative) } \\
0.001 \text { (Combination vs Silodosin) }\end{array}$ \\
\hline & & 7. $\mathrm{Nu}$ & Patie & 'hich Pass & ne Until & Day of Treatment \\
\hline
\end{tabular}




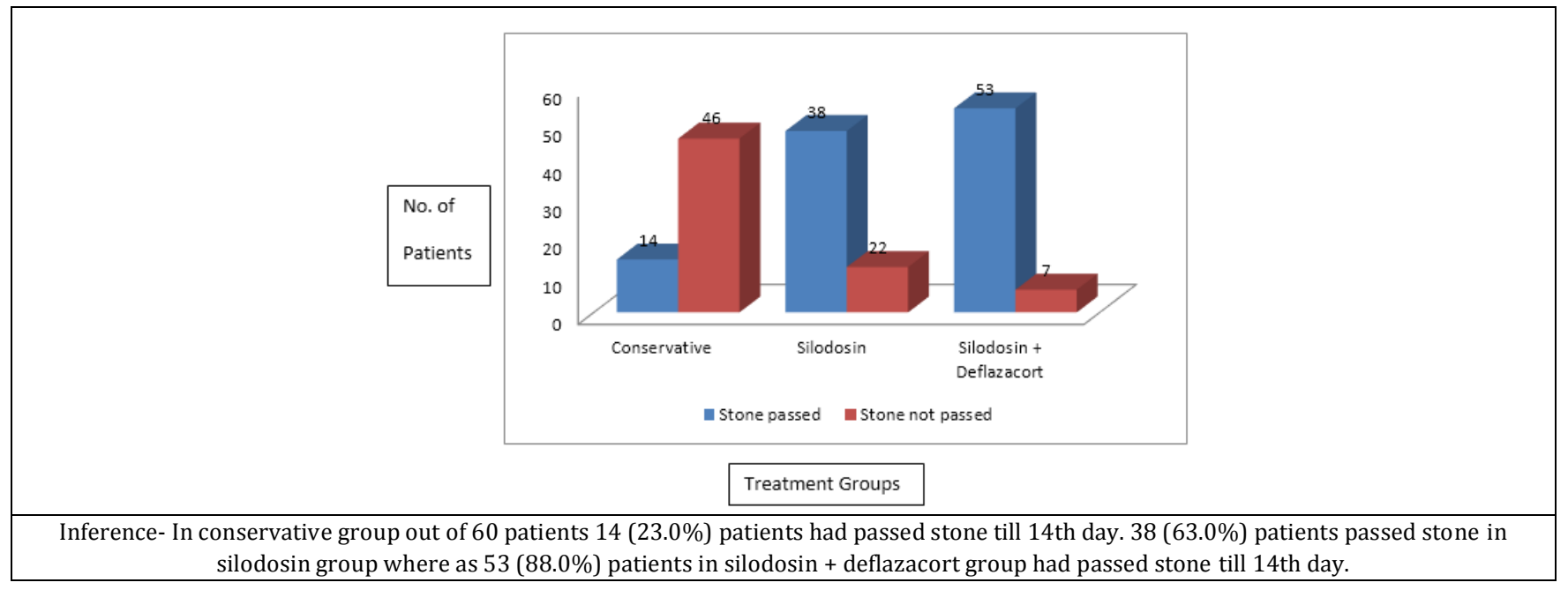

\begin{tabular}{|c|c|c|c|c|c|c|c|}
\hline & \multicolumn{2}{|c|}{ Conservative } & \multicolumn{2}{c|}{ Silodosin } & \multicolumn{2}{c|}{ Silodosin + Deflazacort } & p-Value \\
\hline & $\begin{array}{c}\text { No. of } \\
\text { Patients (n) }\end{array}$ & $\%$ of Patients & $\begin{array}{c}\text { No. of } \\
\text { Patients (n) }\end{array}$ & $\begin{array}{c}\text { \% of } \\
\text { Patients }\end{array}$ & $\begin{array}{c}\text { No. of } \\
\text { Patients (n) }\end{array}$ & $\begin{array}{c}\text { \% of } \\
\text { Patients }\end{array}$ & \\
\hline $\begin{array}{c}\text { Stone } \\
\text { Passed }\end{array}$ & 14 & $23.0 \%$ & 42 & $70.0 \%$ & 53 & $88.0 \%$ & $\begin{array}{c}<0.001 \text { (Combination vs Conservative) } \\
0.01 \text { (Combination vs Silodosin) }\end{array}$ \\
\hline \multicolumn{7}{|c|}{ Table 8. Number of Patients Which Passed Stone Until 21st Day of Treatment } \\
\hline
\end{tabular}

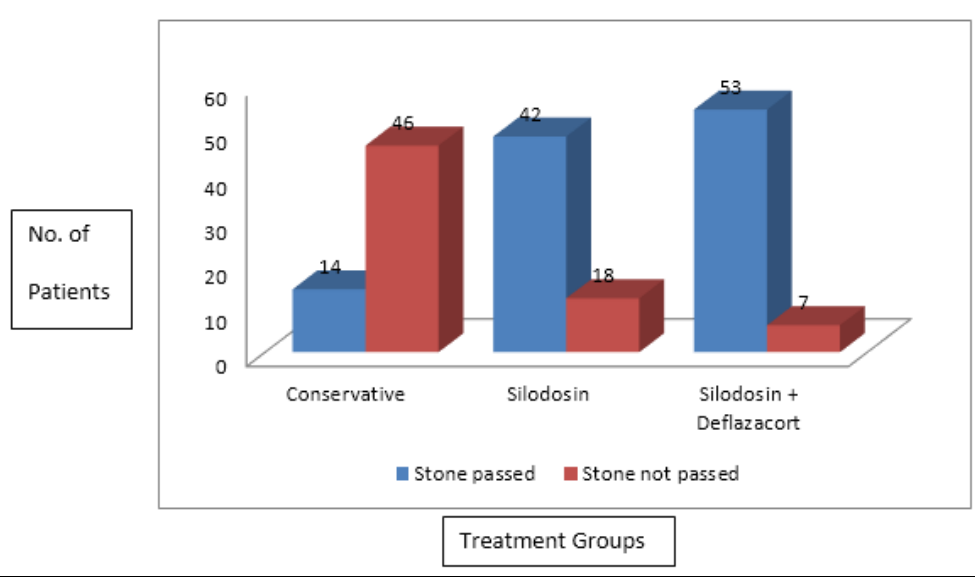

Inference- In conservative group out of 60 patients 14 (23.0\%) patients had passed stone till 21st day. 42 (70.0\%) patients passed stone in silodosin group where as $53(88.0 \%)$ patients in silodosin + deflazacort group had passed stone till 21st day.

\begin{tabular}{|c|c|c|c|c|c|c|c|}
\hline & \multicolumn{2}{|c|}{ Conservative } & \multicolumn{2}{|c|}{ Silodosin } & \multicolumn{2}{|c|}{ Silodosin + Deflazacort } & \multirow[t]{2}{*}{ p-Value } \\
\hline & $\begin{array}{c}\text { No. of } \\
\text { Patients (n) }\end{array}$ & $\begin{array}{c}\% \text { of } \\
\text { Patients }\end{array}$ & $\begin{array}{c}\text { No. of } \\
\text { Patients (n) }\end{array}$ & $\begin{array}{c}\% \text { of } \\
\text { Patients }\end{array}$ & $\begin{array}{c}\text { No. of Patients } \\
\text { (n) }\end{array}$ & $\begin{array}{c}\% \text { of } \\
\text { Patients }\end{array}$ & \\
\hline Stone Passed & 14 & $23.0 \%$ & 48 & $76.0 \%$ & 54 & $90.0 \%$ & $\begin{array}{c}<0.001 \text { (Combination vs Conservative) } \\
0.04 \text { (Combination vs Silodosin) }\end{array}$ \\
\hline
\end{tabular}

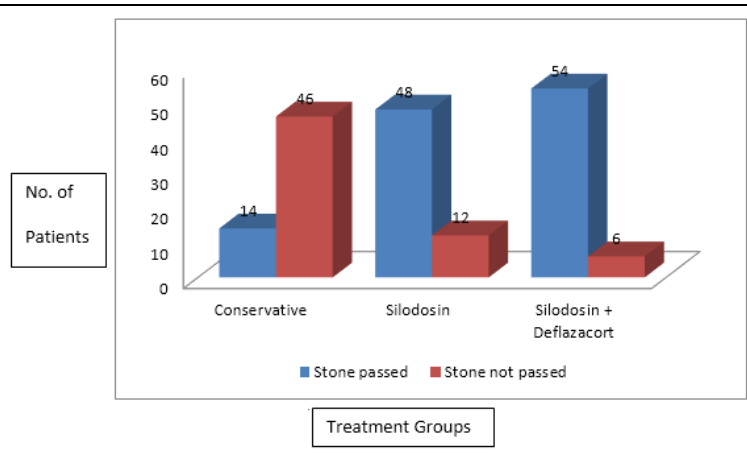

Inference- In conservative group out of 60 patients 14 (23.0\%) patients had passed stone till 28th day. 48 (76.0\%) patients passed stone in silodosin group where as $54(90 \%)$ patients in silodosin + deflazacort group had passed stone till 28 th day. The $P$ value is less than 0.001 between silodosin and silodosin + deflazacort. Therefore, it is considered to be statistically significant. 


\section{DISCUSSION}

Ureteric stones have emerged as a global health issue. Almost $20 \%$ of urinary tract stones are found in the ureter with majority $(70 \%)$ being located in the lower third of the ureter. Medical Expulsive Therapy (MET) has its basis in several physiologic premises.

The ureter is lined by smooth muscle cells that respond to variations in calcium ion concentrations. An increase in calcium levels causes ureteric muscle contraction, conversely a decrease leads to relaxation. Furthermore, smooth muscle cells are densely populated with $\alpha$-1-adrenergic receptors, especially in the distal third of the ureter. Receptor blockade inhibits basal smooth muscle tone and hyper peristaltic uncoordinated frequency whilst maintaining tonic propulsive contractions.

MET has recently emerged as an alternative strategy for the initial management of small distal ureteral stones. The specific mechanism of action on the ureteral smooth muscle and the emerging evidence of the efficacy (Defined as either an increase in expulsion rate or a decrease in time to expulsion) and low-risk profile suggest that $\alpha$-adrenergic receptor antagonists ( $\alpha$-blockers like silodosin) and calcium channel antagonists should be the initial medical treatment in patients amenable to conservative therapy.

Inflammation and edema pose a significant obstacle to the spontaneous passage of stones and anti-inflammatory drugs should be added. The most frequently used drugs in this context are corticosteroids, which are given in association with $\alpha$-1-adrenergic receptor antagonists and calciumchannel blockers because of their action of decreasing edema and inflammation and thereby facilitating the passage of the stone. MET should be offered as a treatment for patients with distal ureteric calculi who are amenable to a waiting management.

This study was conducted in People's College of Medical Sciences and Research Centre, Bhopal. A total of 180 patients with diagnosis of lower ureteric calculi were selected and were randomly divided into 3 equal treatment groups. 1st group comprising of 60 patients was managed with supportive and symptomatic therapy, whereas 2nd group comprising of 60 patients was given silodosin $8 \mathrm{mg}$ daily along with supportive medication. 60 patients of 3 rd group were given silodosin and deflazacort in addition to symptomatic medication. Patients were followed up on 7 th, 14 th, 21st and 28th day for stone clearance and side effect of drugs.

Majority of the patients were in the age group of 15-30 years. Most of the studies have reported a male to female ratio between $3: 1$ and $2: 1$. In our study this ratio was $1.8: 1$. In the first group (Conservative) $66.6 \%(n=40)$ were male patients and $33.3 \%(n=20)$ were female patients.

In the second group (silodosin) male patients were $70 \%$ $(n=42)$ and females were $30.0 \%(n=18)$, in third group (Silodosin with deflazacort) male were $56.1 \%(n=34)$ and females were $42.9 \%(n=26)$.
Males are three times more likely to be afflicted for urinary stone disease. Men appear to excrete more oxalate in their urine and women excrete more citrate, that may explain low incidence of stone diseases in females. We had 110 patients with right lower ureteric calculi and 70 patients with left lower ureteric calculi. Most of the series found calculi with equal frequency on either side.

While alpha - blockers are currently the only recommended monotherapy, corticosteroids have received increased attention as a potential useful adjunct in the medical management of distal ureteric stones.

Medical expulsive therapy with alpha - blockers (Silodosin) is effective for management of lower ureteric calculi and avoids surgical intervention in many patients. Addition of a corticosteroid improves stone clearance rate significantly and hence addition of corticosteroid can be recommended as a standard medical expulsive therapy.

\section{CONCLUSION}

1. Medical expulsive therapy with alpha-blockers (Silodosin) and corticosteroids (Deflazacort) is effective for management of lower ureteric calculi and avoids surgical intervention in many patients.

2. Silodosin alone or in combination with deflazacort significantly increases the stone expulsion rate of lower ureteric calculi in comparison to conservative management.

3. Silodosin alone or in combination with deflazacort also achieves earlier expulsion of stones from lower ureter as compared to conservative management.

4. Addition of deflazacort to silodosin apparently improves the stone clearance rate and decreases the time for stone expulsion.

5. Addition of deflazacort to silodosin improves the stone clearance rate and it is also statistically significant.

6. Addition of deflazacort beyond 14 days does not significantly increase stone expulsion rate.

\section{REFERENCES}

[1] Sutton RA, Walker VR. Responses to hydrochlorothiazide and acetazolamide in patients with calcium stones: evidence suggesting a defect in renal tubular function. $\mathrm{N}$ Engl $\mathrm{J}$ Med 1980;302(13):709-13.

[2] Morse RM, Resnick MI. Ureteral calculi: natural history and treatment in the era of advanced technology. J Urol 1991;145(2):263-5.

[3] Glowacki LS, Beecroft ML, Cook RJ, et al. The natural history of asymptomatic urolithiasis. J Urol 1992;147(2):319-21.

[4] Ehreth JT, Drach GW, Arnett ML, et al. Extracorporeal shock wave lithotripsy: multicenter study of kidney and upper ureter versus middle and lower ureter treatments. J Urol 1994;152(5 Pt 1):1379-85. 